\title{
COMMODITY TURNOVER: A DELAYED FALL ${ }^{1}$ \\ G.Idrisov, Yu.Ponomarev
}

In late 2014 - early 2015, retail and wholesale trade, the one of the biggest sector of Russian economy $y^{1}$, longer than others 'put up resistance' to the negative macroeconomic trends and showed an increase, however small, in commodity turnover. Meanwhile, in the autumn of 2015, in spite of a relative stabilization of Russian terms of trade and foreign exchange rate dynamics, commodity turnover in Russia experienced its sharpest downfall since 2000. This phenomenon is largely explained by the delayed pass-through effect of the ruble's exchange rate fluctuations into commodity prices and by the gradual adaptation of households to new permanent income.

According to Rosstat, in September 2015, retail turnover amounted to $\mathrm{Rb} 2,335.9 \mathrm{bn}$ (or to $89.6 \%$ of the retail turnover, registered in comparable prices in the same period of 2014) $)^{2}$, while wholesale trade turnover amounted to $\mathrm{Rb} 4,290.1 \mathrm{bn}(88.7 \%)^{3}$. At the same time, in September, the share of food commodities including beverages and tobacco products in retail turnover slightly increased - to $47.8 \%$ (vs. $46.6 \%$ in September 2014), while the share of non-food commodities declined to $52.2 \%$ (vs. 53.4\%).

In the structure of wholesale trade, the share of organizations trading in food commodities, including beverages and tobacco products, increased from $20.6 \%$ in September 2014 to $22.7 \%$ in September 2015, while the share of organizations trading in non-food commodities grew from $15.1 \%$ to $15.9 \%$. In the main, this growth occurred at the expense of a notable decline in the share of organizations engaged in wholesale trade in non-agricultural intermediate products, waste and scrap $^{4}$ (from $47.9 \%$ to $43.0 \%$ ).

At the same time, in spite of the negative trends dominating Russia's trade sector, the largest retailers (retail chains) account for a large proportion of commodity turnover ${ }^{5}$ and continue to show positive financial results $^{6}$. In other words, traditional formats of trade account for almost all the decline in retail turnover.

The key factors behind the drop in retail and wholesale trade turnover are as follows:

1 According to Rosstat in 2010 - 2014 the share of wholesale and retail trade in gross value added amounted to $18 \%$ (in constant prices).

2 See: The Short-Term Economic Indicators of the Russian Federation. The Federal State Statistics Service of the Russian Federation (Rosstat). September 2015.

3 See: The Social and economic Situation in Russia. Rosstat. September 2015.

4 Including fossil fuels, metals and metal ores, timber, construction materials and sanitary appliances, machines and equipment, and other goods.

5 According to Rosstat, during the past few years, the share of retail chains in the total volume of Russia's retail turnover was gradually increasing. In 2014, it amounted to $22.4 \%$.

6 Thus, for example, X5 Retail Group has announced that in Q3 2015 its revenues increased by $28.6 \%$ [http://www.x5.ru/common/img/uploaded/files/press_releases/2015/Q3_2015_ Trading_Update_RUS.pdf], while the grocery retail chain Magnit has announced that in September 2015 its revenues (in rubles) increased by $19.31 \%$ [http://www.acort.ru/pressroom/news2/1149-magnit-ob-yavlyaet-o-roste-vyruchki-za-sentyabr-2015-goda-na-19-31-vrublyakh.html]. 
- the decline in real household disposable income (by $4.3 \%$ in September, and by $3.3 \%$ during the period January-September 2015 , relative to the same periods of 2014), and expectations of further decline;

- the rise in consumer prices (by $0.6 \%$ in September and by $10.4 \%$ during the period January-September 2015), and expectations of their further rise;

- the possible shift in durable goods consumption towards the end of 2014 - early 2015, the period when rush demand was registered;

- customer defection from retail chain stores and independent stores to corner food markets.

The reduction in the household disposable income is a result of economic agents' adaptation to the new macroeconomic conditions, while the rise in prices - a result of the pass-through effect of the ruble's exchange rate fluctuations ${ }^{1}$.

Retail chains and traditional formats of trade represent a link between producers/suppliers and customers and are traditionally subjected to political pressure and consumer discontent with the growth of consumer prices ${ }^{2}$. In their turn, the retail chains and non-chain stores transmit this pressure to the producers ${ }^{3}$. As a result, there exists a constant tension between retail chains and producers, which is determined, on the one hand, by the tug of war for profit margins, and on the other hand - by their resentment over the 'unfair' distribution of the mutually created added value 4 .

In Russia, the numerous efforts at resolving such disputes via the selfregulation mechanism of the trade sector have so far proven to be futile. The upshot was that the sector had to be subjected to legislative pressure on 21 January 2015 a draft law on the introduction of amendments to the Trade Law was introduced into the State Duma of Russian Federation ${ }^{5}$. The draft law, which has so far been passed in the first reading, significantly increases the regulatory burden imposed on the trade sector. However, it should be said that the parliamentary debate over the draft law is far from the end.

At the same time, Russian consumers should be ready not only to witness the continuing confrontation between retail chains and producers, but

1 For more details, see G. I. Idrisov, A. S. Kaukin, Yu. Yu. Ponomarev. The Pass-Through Effect: The Rise in Prices in Industry Will Continue. Online Monitoring of Russia's Economic Outlook.. 2015. No 4, p.p. 12-14.

2 For example, such a situation has led to the mass inspections of retailers undertaken by the RF Prosecutor General's Office (see URL: [http://genproc.gov.ru/smi/news/genproc/news741416/]; [http://tass.ru/ural-news/1772419]).

3 In late February 2015, a number of retail chains announced that the prices of major socially important commodities would be frozen for two months (see URL: [http://www.acort.ru/ press-room/news/778-torgovye-seti-vvodyat-spetsialnye-mery.html]). Later on, however, the largest retail chains invited their suppliers to discuss the possible ways to mutually curb the growth of prices under the current adverse economic conditions (for more details, see URL: [http://tass.ru/ekonomika/2402895]).

4 At the same time, official statistics do not permit to make unambiguous conclusions in favor of any of the conflicting parties. See G. I. Idrisov, Yu. Yu. Ponomarev. Retail Trade: Producers Versus Retail Chains. Online Monitoring of Russia's Economic Outlook. 2015. No 9. P.p. 28-33.

5 Federal Law, of 28 December 2009, No 381-FZ (as amended on 31 December 2014) 'On the Fundamental Principles of State Regulation of Trade in the Russian Federation' (entered into force, with alterations and amendments, on 9 January 2015). 
Table 1

ACTUAL CHANGES OF CONSUMER PRICES AND THE MAGNITUDE OF THE PASS-THROUGH EFFECT

\begin{tabular}{|c|c|c|c|c|c|c|}
\hline & & & \multicolumn{4}{|c|}{2015} \\
\hline & & & Sept & Oct & Nov & Dec \\
\hline \multirow{4}{*}{ 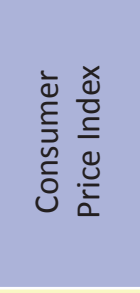 } & \multirow[b]{2}{*}{$\begin{array}{l}\text { Actual change } \\
\text { of prices }\end{array}$} & In $\%$, relative to previous month & 100.6 & 100.7 & & \\
\hline & & $\begin{array}{c}\text { Accumulated result since } \\
\text { beginning of } 2015, \%\end{array}$ & 110.6 & 111.4 & & \\
\hline & \multirow{2}{*}{$\begin{array}{l}\text { Assessment of } \\
\text { change of prices } \\
\text { due to pass- } \\
\text { through effect }\end{array}$} & In $\%$, relative to previous month & 100.4 & 102.2 & 100.6 & 101.1 \\
\hline & & $\begin{array}{l}\text { Accumulated result since } \\
\text { beginning of } 2015, \%\end{array}$ & 110.6 & 111.4 & 112.0 & 113.2 \\
\hline \multirow{4}{*}{ 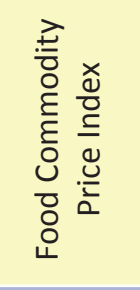 } & \multirow{2}{*}{$\begin{array}{l}\text { Actual change } \\
\text { of prices }\end{array}$} & In \%, relative to previous month & 100.4 & 101.0 & & \\
\hline & & $\begin{array}{l}\text { Accumulated result since } \\
\text { beginning of } 2015, \%\end{array}$ & 110.4 & 111.5 & & \\
\hline & \multirow{2}{*}{$\begin{array}{l}\text { Assessment of } \\
\text { change of prices } \\
\text { due to pass- } \\
\text { through effect }\end{array}$} & In $\%$, relative to previous month & 100.7 & 102.2 & 100.3 & 101.9 \\
\hline & & $\begin{array}{l}\text { Accumulated result since } \\
\text { beginning of } 2015, \%\end{array}$ & 110.4 & 112.8 & 113.1 & $11 . .3$ \\
\hline \multirow{4}{*}{ 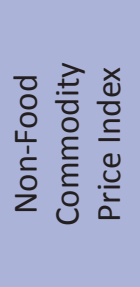 } & \multirow{2}{*}{$\begin{array}{l}\text { Actual change } \\
\text { of prices }\end{array}$} & In $\%$, relative to previous month & 100.6 & 101.0 & & \\
\hline & & $\begin{array}{c}\text { Accumulated result since } \\
\text { beginning of } 2015, \%\end{array}$ & 109.2 & 110.3 & & \\
\hline & \multirow{2}{*}{$\begin{array}{l}\text { Assessment of } \\
\text { change of prices } \\
\text { due to pass- } \\
\text { through effect }\end{array}$} & In $\%$, relative to previous month & 100.9 & 102.3 & 100.4 & 101.0 \\
\hline & & $\begin{array}{l}\text { Accumulated result since } \\
\text { beginning of } 2015, \%\end{array}$ & 109.2 & 111.7 & 112.1 & 113.2 \\
\hline
\end{tabular}

Source: Rosstat, authors' estimates.

also to prepare themselves to a further rise in consumer prices, determined by the pass-through effect of the ruble's exchange rate into prices ${ }^{1}$. Thus, according to our estimates, by the end of 2015 , consumer prices will rise by up to $13.2 \%$ per annum, including due to the delayed pass-through effect.

1 Yu. Ponomarev, P. Trunin, A. Ulyukayev. Exchange Rate Pass-Through in Russia. Voprosy Ekonomiki. Moscow, 2014, No 3. 